\title{
Violence among community elderly and its relationship with the nutritional status and sociodemographic characteristics
}

How to cite this article: Brandão WFM, Souza MA, Araújo GKN, Santos RC, Almeida LR, Souto RQ. Violence among community elderly and its relationship with the nutritional status and sociodemographic characteristics. Rev Gaúcha Enferm. 2021;42:e20200137. doi: https://doi.org/10.1590/19831447.2021.20200137 a Universidade Federal da Paraíba (UFPB). João Pessoa, Paraíba, Brasil.

\author{
Violência entre idosos comunitários e sua relação com o estado \\ nutricional e características sociodemográficas
}

Violencia entre ancianos de la comunidad y su relación con características nutricionales y sociodemográficas

\section{Wesley Ferreira de Moraes Brandão Matheus Araruna de Souza ${ }^{a}$ Gleicy Karine Nascimento de Araújo ${ }^{a}$ Renata Clemente dos Santos ${ }^{\mathrm{a}}$ Luana Rodrigues de Almeida ${ }^{a}$ Rafaella Queiroga Souto ${ }^{a}$}

\section{ABSTRACT}

Objective: To verify the prevalence of violence among elderly community members and its relationship with nutritional status and sociodemographic characteristics.

Method: Cross-sectional and analytical study developed with 159 community elderly registered at a Family Health Unit in Recife/ Pernambuco between March 2016 and March 2017. The Brazil Old Age Schedule, Conflict Tactics Scales and Mini Nutritional Assessment were used as data collection instruments. Data received descriptive and inferential statistical treatment.

Results: Among the elderly classified as with violence, there was a predominance of psychological violence (64.3\%), and the majority were at risk for malnutrition (54.3\%). There was an association between 'having a partner' and psychological (48.1\%; $\mathrm{p}=0.02$ ) and physical (48.1\%; $\mathrm{p}=0.03$ ) violence. Logistic regression demonstrated that being in a relationship or being malnourished increases the likelihood of suffering psychological violence $(O R=2.63 ; O R=3.67)$, just as not being working increases the likelihood of physical violence $(0 R=5.61)$.

Conclusion: Violence was negatively related to the nutritional status of elderly community members.

Keywords: Frail elderly. Elder abuse. Elderly nutrition. Gender-based violence. Domestic violence. Intimate partner violence.

RESUMO

Objetivo: Verificar a prevalência da violência entre idosos comunitários e sua relação com o estado nutricional e características sociodemográficas

Método: Estudo transversal, desenvolvido com 159 idosos comunitários cadastrados em Unidade de Saúde da Família em Recife/ Pernambuco entre março de 2016 e março de 2017. Foram utilizados Brazil Old Age Schedule, Conflict Tactics Scales e Mini Nutritional Assessment como instrumentos de coleta. Os dados receberam tratamento estatístico descritivo e inferencial.

Resultados: Dentre os idosos considerados com violência, houve predomínio da violência psicológica (64,3\%), e a maioria possuía risco para desnutrição (54,3\%). Verificou-se associação entre 'ter um companheiro' e a violência psicológica $(48,1 \% ; p=0,02)$ e física (48,1\%; $p=0,03)$. A regressão logística demonstrou que ter um companheiro ou estar desnutrido aumenta a probabilidade de sofrer violência psicológica $(O R=2,63 ; O R=3,67)$, assim como não estar trabalhando aumenta a probabilidade de violência física $(\mathrm{OR}=5,61)$.

Conclusões: A violência se relacionou negativamente ao estado nutricional dos idosos comunitários.

Palavras-chave: Idoso fragilizado. Abuso de idosos. Nutrição do idoso. Violência de gênero. Violência doméstica. Violência por parceiro íntimo.

RESUMEN

Objetivo: Verificar la prevalencia de violencia entre ancianos de la comunidad y su relación con el estado nutricional y las características sociodemográficas.

Método: Estudio transversal and analítico realizado con 159 ancianos de la comunidad registrados en una unidad de salud familiar en Recife/Pernambuco. Se utilizó el Brazil Old Age Schedule; Conflict Tactics Scales y Mini Nutritional Assessment como instrumentos de recolección. Los datos recibieron tratamiento estadístico descriptivo e inferencial.

Resultados: Entre los ancianos clasificados con violencia, predominaba la violencia psicológica (64,3\%), y la mayoría de ellos están en riesgo de desnutrición (54,3\%). Hubo una asociación entre'tener pareja'y violencia psicológica $(48,1 \%$; $p=0,02)$ y física $(48,1 \%$; $p=0,03)$. La regresión logística demostró que estar en una relación o estar desnutrido aumenta la probabilidad de sufrir violencia psicológica ( $O R=2,63 ; 0 R=3,67)$, así como, no estar trabajando aumenta la probabilidad de violencia física ( $O R=5,61)$ Conclusión: La violencia se relacionó negativamente con el estado nutricional de los ancianos de la comunidad.

Palabras clave: Anciano frágil. Abuso de ancianos. Nutrición del anciano. Violencia de género. Violencia doméstica. Violencia de pareja. 


\section{IINTRODUCTION}

During the aging process, it is common for some tissue changes to appear, such as the decrease in lean body mass (reduction and atrophy of muscle tissue) and the relocation of adipose tissue deposits, with a decrease in the lower limbs and an increase in fat in the torso and viscera ${ }^{(1)}$. Such changes trigger the emergence of clinical syndromes that interfere with the autonomy and functional capacity of the elderly. One of them is frailty, which can be evidenced by the decrease in strength, endurance and physiological function of the elderly ${ }^{(1)}$.

Such changes result in increased dependency and vulnerability to abuse. Violence against the elderly person (VAEP) is characterized by "action, single or repeated, or the absence of an appropriate action, intentional or not, which brings unnecessary harm or distress to the elderly person, reducing their quality of life". This phenomenon can present itself in the form of abuse (physical, psychological, sexual, financial, abandonment), negligence and self-negligence ${ }^{(2)}$.

The scenarios where violence occurs are diverse and range from the home environment to health services. Signs that indicate ill-treatment of the elderly are considered: repeated visits to medical care, either in the office or in emergency rooms; conflicting stories; delays in seeking treatment; unexplained, inconsistent, or vague injuries; history of accident predisposition; ambivalence, anger or fear towards the caregiver; poor adherence to the care plan and evidence of physical injuries ${ }^{(2)}$.

Globally, it is reiterated that $10 \%$ of elderly people are affected by violence, achieving death or not ${ }^{(3)}$. In Latin America, about $37 \%$ of the elderly population suffers some type of violence, with Brazil being considered one of the most violent countries. Indicators show the prevalence of abandonment in $10.3 \%$ and physical aggression in $6.3 \%$ (4).

In this context, it is observed that the functional dependence of the elderly makes them more likely to suffer violence ${ }^{(5)}$. This negatively impacts the victims' health, and may result in varied psychopathological outcomes, also encompassing eating disorders. Thus, it reflects the possibility of food negligence, especially with elderly people who are highly dependent on their caregivers ${ }^{(2,5)}$.

Considering the problematization raised so far, the scarcity of research indicating the existence of this relationship, and its verification being feasible, it justifies the development of studies for this purpose. Thus, it is questioned: how is the occurrence of violence among community elderly verified and what is its relationship with nutritional status and sociodemographic characteristics? Therefore, this study aimed to verify the prevalence of violence among community elderly and its relationship with nutritional status and sociodemographic characteristics.

\section{METHODS}

Cross-sectional, descriptive study with a quantitative approach, carried out between March 2016 and March 2017, in a Basic Health Unit (BHU), located in microregion III, of the Sanitary District IV, in the city of Recife, Pernambuco, Brazil. It was submitted for evaluation under protocol CAAE 51557415.9.0000.5208 and approved by the Research Ethics Committee of the Center for Health Sciences (CHS) of the Universidade Federal de Pernambuco (UFPE), under opinion number 1.413.599.

The aforementioned BHU houses three family health teams and was chosen because it is located next to the UFPE, enabling the development of a social responsibility initiative by the University in relation to its community. The study data come from a larger research project entitled "Impact of multidimensional interventions on elderly registered in primary health care and their caregivers".

The study population consisted of 1209 elderly, enrolled in teams linked to the BHU. Sample calculation was performed using the finite population formula for epidemiological studies, with a significance level of 95\% and an 8\% margin of error. The final sample resulted in 159 participants.

Sampling was random of the systematic type. The research participants were drawn, and the proportionality between the three teams working in the unit was respected. For every five elderly people present on the list of one of the three teams, one was selected and invited to participate in the research. The Community Health Agents (CHA) accompanied a pair of trained researchers to the residence of the selected elderly person, where collections were carried out on days and times agreed with the participants.

Individuals aged over 60 years, registered at the aforementioned BHU, participated in the study. Elderly people who were in the terminal stage, who had impaired visual and hearing acuity and/or cognitive deficit were excluded from the study. This last criterion was identified through information provided by the $\mathrm{CHA}$.

Participants were informed about the theme and objective of the study. In addition, two copies of the Free and Informed Consent Form (FICF) were provided, one copy signed by the participant and returned to the researcher responsible for the collection - in order to authorize the use of the information obtained there for scientific studies -, and the other was provided to the participant, containing information about the study, responsible researcher and signature of the researcher who carried out the collection. 
The following instruments were used in data collection: Brazil Old Age Schedule (BOAS) questionnaire; Revised Version of the Conflict Tactics Scales Form (CTS1-R); Mini Nutritional Assessment (MNA).

The sociodemographic profile was drawn using the BOAS questionnaire, which covers the various dimensions of the elderly person and provides important information for assessing this population, such as characteristics, needs and problems. It was validated for the Brazilian population and is divided into nine sections, where sections one to eight refer to the interviewee and nine to the interviewer ${ }^{(6)}$. For the purposes of this study, the variables age, gender, marital status, educational level, work and income were extracted from that instrument ${ }^{(6)}$.

The CTS-1 form $R$ is valid for the Brazilian population, having been cross-culturally adapted ${ }^{(7)}$. As the sample of the study in question consisted of couples, the authors verified the sensitivity of the instrument in this audience. However, considering the unspecific nature of the instrument, with regard to the population to be investigated, and considering the different concepts of family and diversity of family configurations and arrangements, using the cross-cultural adaptation of the instrument in national studies is plausible due to the semantic adaptations made, and so far, there are no scientific findings that support the "non-use" of the instrument in heterogeneous samples from the aforementioned study.

At the time of data collection, the collector sought to make it clear that the questions being asked to the interviewee could be related to situations that had occurred with any member of the family. Furthermore, it is the only instrument with psychometric properties for measuring violence, used in several studies with different population groups, reaffirming that its use is not exclusive for couples, nor is it excluded from this group.

The CTS1-R is an instrument used to assess intrafamily violence. It encompasses three strategies for dealing with conflicts, which are argumentation, verbal violence and physical violence. The items on the scale are listed from A to $S$ and are composed of situations in which family members may come into conflict ${ }^{(7)}$. The instrument consists of 19 questions divided between the dimensions of psychological and physical violence. A positive answer between the questions related to the respective facet and type of violence positively characterizes the situation of intrafamily violence ${ }^{(7)}$. The scores of all questions were added, obtaining a total score. All elderly who had an affirmative case for physical and psychological violence, or one of the two, were classified as 'with violence'.
The MNA is a standardized instrument, developed with the objective of assessing the nutritional status of elderly people in a simple and fast way. It is divided into two parts and consists of 18 items, 6 on screening and 12 on nutritional assessment. Finally, it classifies the score obtained into: normal (12-14 points), risk of malnutrition (8-11 points) and malnourished (1-7 points) ${ }^{(8)}$.

In sequence, the data were analyzed using the Statistical Package for the Social Sciences (SPSS), using descriptive (absolute and relative frequency) and inferential statistics (Pearson's Chi-Square Test or Fisher's Exact Test; Multiple Logistic Regression Model), in order to determine the significance between the dependent variable (with or without violence) and the independent (socioeconomic and nutritional status data). A level of statistical significance of $p<0.05$ was adopted between the variables. For the logistic regression model, the variables that presented $p<0.2$ in the bivariate analysis were included.

\section{$\square$ RESULTS}

The sample consisted of 159 elderly people, with a prevalence of females; $(76.7 \%, \mathrm{n}=122)$; age less than or equal to 70 years (54.1\%; $n=86)$; without a partner $(66.0 \% ; n=65)$; no employment contract (82.4\%; $n=126)$. Furthermore, they had an income equal to or less than the minimum wage $(71.1 \%$; $\mathrm{n}=113)$ and knew to read and write (66.7\%; $\mathrm{n}=106)$. The risk for malnutrition prevailed (54.3\%; $n=82)$, with no outcome for psychological (64.3\%; $n=99)$ and physical violence $(93.5 \%$; $n=145$ ). Table 1 shows the frequency distribution of socioeconomic variables, nutritional status and violence among study participants.

As shown in Table 2, the outcome of physical and psychological violence prevailed among the elderly with the following characteristics: age less than or equal to 70 years; women; able to read and write; exercised some work activity; they had an income above the minimum wage and were in a state of malnutrition. Having a partner was associated with psychological $(p=0.02)$ and physical $(p=0.03)$ violence.

Table 3 shows the results of the logistic regression test, showing that elderly people with a relationship are 2.63 times more likely to be victims of psychological violence, and the malnourished 3.67 times more likely to be affected by that type of violence. In relation to physical violence, the variable that remained in the model was work, so that elderly people who do not work are 5.61 times more likely to occur. 
Table 1 - Frequency distribution of socioeconomic, nutritional status and violence variables among participants. Recife, PE, Brazil, 2016-2017 ( $n=159)$

\section{Variables}

Gender

Male

37

Female

122

86

73

Over 70

\section{Marital status}

With partner

54

Without partner

65

\section{Works}

Yes

No

126

\section{Income}

Up to a minimum wage

More than one

minimum wage

\section{Knows to read and write}

Yes

No

\section{Nutritional status}

Normal

51

82

Risk of malnutrition

Malnourished

18

\section{Psychological violence}

Yes

No

55

99
54.1

45.9

34.7

\section{Valid/missing Sample}

159/0

76.7

34.0

$119 / 40$

66.0

17.6

$153 / 6$

82.4

71.1

$159 / 0$

28.9

66.7

159/0

33.3

33.8

$151 / 8$

54.3

11.9

64.3

$154 / 5$ 
Table 1 - Cont.

\section{Variables}

Physical violence

Yes

No

Source: Research data, 2016-2017. n

10

145
$\%$

Valid/missing Sample

Table 2 - Association between violence variables and socioeconomic variables among participants. Recife, PE, Brazil, 2016$2017(n=159)$

\begin{tabular}{|c|c|c|c|c|}
\hline \multirow{2}{*}{ Variables } & \multicolumn{2}{|c|}{ Psychological Violence } & \multicolumn{2}{|c|}{ Physical Violence } \\
\hline & $\begin{array}{l}\text { With } \\
\text { n (\%) }\end{array}$ & $\begin{array}{c}\text { Without } \\
\text { n (\%) }\end{array}$ & $\begin{array}{l}\text { With } \\
\text { n (\%) }\end{array}$ & $\begin{array}{c}\text { Without } \\
\text { n (\%) }\end{array}$ \\
\hline \multicolumn{5}{|l|}{ Age } \\
\hline Between 60 and 70 & $33(39.8)$ & $50(60.2)$ & $8(9.5)$ & $76(90.5)$ \\
\hline Over 70 & $22(31.0)$ & $49(69.0)$ & $2(2.8)$ & $69(97.2)$ \\
\hline p-value & \multicolumn{2}{|c|}{$0.25^{*}$} & \multicolumn{2}{|c|}{$0.11^{* *}$} \\
\hline \multicolumn{5}{|l|}{ Gender } \\
\hline Male & $12(33.3)$ & $24(66.7)$ & $12(33.3)$ & $24(66.7)$ \\
\hline Female & $43(36.4)$ & 75 (63.6) & $44(37.3)$ & $74(62.7)$ \\
\hline p-value & \multicolumn{2}{|c|}{$0.73^{*}$} & \multicolumn{2}{|c|}{$0.66^{*}$} \\
\hline \multicolumn{5}{|l|}{ Marital status } \\
\hline With partner & $25(48.1)$ & $27(51.9)$ & $25(48.1)$ & $27(51.9)$ \\
\hline Without partner & $30(29.4)$ & $72(70.6)$ & $31(30.4)$ & $71(69.6)$ \\
\hline p-value & \multicolumn{2}{|c|}{$0.02 *$} & \multicolumn{2}{|c|}{$0.03^{*}$} \\
\hline \multicolumn{5}{|c|}{ Knows to read and write } \\
\hline Yes & $38(36.9)$ & $65(63.1)$ & $39(37.9)$ & $64(62.1)$ \\
\hline No & $17(33.3)$ & $34(66.7)$ & $17(33.3)$ & $34(66.7)$ \\
\hline p-value & \multicolumn{2}{|c|}{$0.66^{*}$} & \multicolumn{2}{|c|}{$0.58^{*}$} \\
\hline \multicolumn{5}{|l|}{ Works } \\
\hline Yes & $10(40.0)$ & $15(60.0)$ & $10(40.0)$ & $15(60.0)$ \\
\hline No & $44(35.8)$ & $79(64.2)$ & $45(36.6)$ & $78(63.4)$ \\
\hline
\end{tabular}


Table 2 - Cont.

\begin{tabular}{|c|c|c|c|c|}
\hline \multirow[b]{2}{*}{ Variables } & \multicolumn{2}{|c|}{ Psychological Violence } & \multicolumn{2}{|c|}{ Physical Violence } \\
\hline & $\begin{array}{l}\text { With } \\
\text { n (\%) }\end{array}$ & $\begin{array}{c}\text { Without } \\
\text { n (\%) }\end{array}$ & $\begin{array}{l}\text { With } \\
\text { n (\%) }\end{array}$ & $\begin{array}{c}\text { Without } \\
\text { n (\%) }\end{array}$ \\
\hline p-value & \multicolumn{2}{|c|}{$0.68^{*}$} & \multicolumn{2}{|c|}{$0.74^{*}$} \\
\hline \multicolumn{5}{|l|}{ Income } \\
\hline Up to a minimum wage & $39(35.1)$ & $72(64.9)$ & $40(36.0)$ & $71(64.0)$ \\
\hline More than one minimum wage & $16(37.2)$ & $27(62.8)$ & $16(37.2)$ & $27(62.8)$ \\
\hline p-value & \multicolumn{2}{|c|}{$0.81^{*}$} & \multicolumn{2}{|c|}{$0.89 *$} \\
\hline \multicolumn{5}{|l|}{ Nutritional status } \\
\hline Normal & $14(28.6)$ & $35(71.4)$ & $14(28.6)$ & $35(71.4)$ \\
\hline Risk of malnutrition & $29(35.8)$ & $52(64.2)$ & $30(37.0)$ & $51(63.0)$ \\
\hline Malnourished & $9(52.9)$ & $8(47.1)$ & $9(52.9)$ & $8(47.1)$ \\
\hline p-value & \multicolumn{2}{|c|}{$0.19^{*}$} & \multicolumn{2}{|c|}{$0.19^{*}$} \\
\hline
\end{tabular}

Source: Research data, 2016-2017.

* Pearson's Chi-square Test; ** Fisher's Exact Test.

Table 3 - Adjusted logistic regression analysis between psychological and physical violence and model variables. Recife, PE, Brazil, 2016-2017 ( $n=159)$

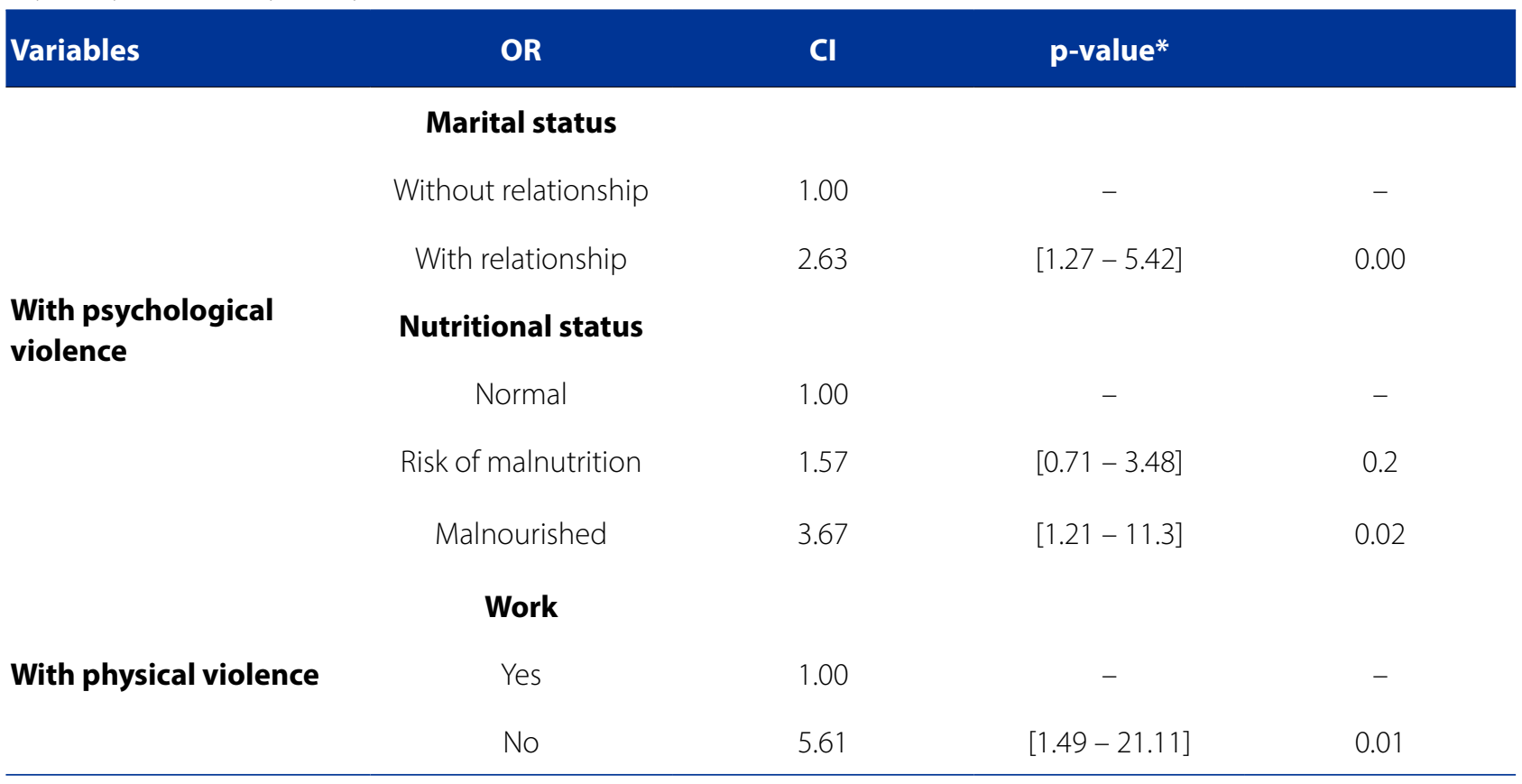

Source: Research data, 2016-2017.

Note: OR - Odds Ratio; Cl - confidence interval; ${ }^{*} \mathrm{p}$-value. 


\section{DISCUSSION}

As demonstrated by the data collected by this study, there is a greater distribution of female community elderly. The feminization of the aging of the general population may be responsible for the predominance of women in this context ${ }^{(3)}$. Elderly women presented themselves as the most likely to suffer physical and psychological violence, when compared to men. Associated with gender, there are factors such as low education and remuneration, loneliness, social isolation and prolonged exposure to chronic diseases ${ }^{(5,9)}$.

The impact of violence by intimate partner among the elderly is still not well understood. Gender violence is prevalent among women in about $20 \%$ to $30 \%$. These data confirm that, depending on the social context, elderly women are more susceptible to domestic violence by the intimate partner than by their family members and caregivers. It is believed that physical violence by an intimate partner decreases with advancing age, while psychological violence remains invariable ${ }^{(9)}$, which may justify the findings of the present study, elucidating the increase in indicators of psychological violence related to female gender.

Individuals who suffer physical violence are more likely to have negative psychological outcomes. Despite the harm, the aggressor's permanence at home is commonly due to the affective characteristics of abusive relationships, for believing in the importance of the partner's presence for the son/daughter's well-being and for believing in changing the attitudes of their partners ${ }^{(9)}$.

Violence between partners has a direct influence on the Body Mass Index (BMI), especially in women who live with low income and who are physically abused by their partners. This rate tends to fall, increasing the risk for malnutrition ${ }^{(10)}$, corroborating the data found on the association between risk for malnutrition or malnutrition and psychological violence.

As for the variable work, it was found that the elderly who do not work are 5.61 more likely to suffer physical violence. This data may be related to the length of stay of the elderly at home, as this can increase their exposure to aggressor agents, who can be the partner with whom they establish a loving bond, caregivers, as well as family members who live in the same residence. The home is a dangerous place for the elderly, particularly for those who have some degree of functional dependence $e^{(5)}$.

Psychological violence and negligence are more prevalent in elderly people living with low wages, urban residents, with more than 5 years of education, when compared to physical, financial and sexual violence ${ }^{(5)}$, confirming the findings of the present study.
Income is directly associated with length of study and is positively correlated with an increase in the Body Mass Index (BMI). Elderly people living with up to a minimum wage are more propense to nutritional disorders, geriatric syndromes and violence ${ }^{(10)}$. Most of the sample that composed the present study lived with the aforementioned income range (71.1\%) and presented a risk of malnutrition (54.3\%).

Financial conditions influence the quality of the elderly's $\operatorname{diet}^{(11)}$. Financial violence is prevalent over them. Although the data from this study show that $113(71.1 \%)$ of the elderly have an income of up to one minimum wage and 46 (28.9\%) earn more than one salary monthly, the elderly may not be responsible for managing their own income, this function being performed by family members, spouses or caregivers, making the elderly vulnerable to financial violence and neglect ${ }^{(12)}$.

In most contexts, the elderly person lives with the aggressor ${ }^{(5)}$. In developing countries, such as Brazil, there is a high rate of financial control by the male spouse, which was associated with high levels of violence ${ }^{(13)}$. Consequently, if the elderly does not have the autonomy to manage their finances, they may suffer from financial insufficiency to purchase foods that meet their dietary demands, in order to compromise their nutritional conditions. We believe that this may be the justification underlying the relationship between psychological and financial violence and the risk of malnutrition.

Considering that the most prevalent family composition is the elderly person who lives with someone $e^{(5)}$, their elderly income may not be sufficient to meet the needs of the family unit, since, for most families, price is the most important factor at the time of purchase of food ${ }^{(11)}$. Furthermore, elderly people who live with family members/spouses/caregivers who are financially dependent on their income are at greater risk of suffering violence ${ }^{(5)}$.

On the other hand, when unaccompanied and in a public environment, the elderly person is 3.1 more likely to suffer financial and property violence ${ }^{(14)}$. That is, whatever the context in which the elderly is immersed, he/she is susceptible to violence, sometimes by the people they live with, sometimes by others. It is worth noting that violence is a culturally taughtlearned behavior. In a society that historically naturalizes violence and denies it in its social ideology ${ }^{(15)}$, cases may be underreported and sometimes not recognized by the people involved, whether victims or perpetrators.

It was possible to establish a relationship between the nutritional status variable and psychological violence. Therefore, the elderly who suffer this violence are 3.67 more likely to be malnourished. Psychological violence is related to the 
elderly person's level of dependence to perform basic and instrumental activities ${ }^{(5)}$. It is believed that food neglect may occur, especially with elderly people who are highly dependent on their caregivers, as psychological/verbal violence usually precedes negligence and physical violence ${ }^{(2)}$.

As for the elderly with a low degree of functional dependence, constant mental damage triggers harms to their mental health ${ }^{(16)}$, which can be externalized through the lack of motivation to perform self-care actions, especially those aimed at eating. Such omission can be interpreted as self-inflicted violence, characterized when the person mistreats itself with frequent self-destructive attitudes, directly or indirectly manifesting the will to $\mathrm{die}^{(2)}$.

The diet low in essential nutrients influences the antisocial behavior of those who consume it and can impactVAEP outcomes, especially when considering the association of nutrition with income, and the latter with the composition of the family unit of which the elderly person is a member. That said, it is illative that healthy nutrition is capable of promoting physical, psychological and social well-being ${ }^{(17)}$, as a diet rich in nutrients is capable of reducing the rates of violence in a population.

Furthermore, physical violence was related to the nutritional status of the elderly, but there was no statistical significance. Senility usually has repercussions on the musculoskeletal system, such as sarcopenia, osteopenia, reduced motor strength and impaired gait ${ }^{(1)}$. Such factors make the elderly more fragile, and this condition can justify the occurrence of physical violence. It is worth remembering the predominance of other forms of violence over this one, which demonstrates that aggressive behavior is still manifested, regardless of how long-lived is the elderly ${ }^{(5)}$.

Low nutrients or malnutrition can exacerbate the decrease in skin wetting and compliance, physiological changes present in senescence, impairing the integrity of this organ and predisposing it to infections, as well as other complications caused by the cascade effect ${ }^{(1)}$. Low vitamin D levels can amplify psychopathological disorders ${ }^{(18)}$, including those related to VAEP, in addition to sharpening osteopenia related to the natural aging process. When evaluating the psychopathological and nutritional damage caused by VAEP, based on the principles of Maslow's Theory ${ }^{(19)}$, it is feasible to conclude that such damage can affect the five hierarchical levels of human needs.

The Basic Human Needs Theory states that human beings naturally have limited ability to adequately reverse these imbalances. Thus, they need a health professional to help them in this process, because if such needs are inadequately or not met, they will cause discomfort, and this, in the long term, will trigger diseases ${ }^{(20)}$. Identifying such imbalances related to VAEP is essential to intervene effectively and early, which can favor positive outcomes for the elderly person.

Nurses can identify signs of violence in the Nursing consultation, including changes in nutritional status, and request an assessment from other professionals involved, such as psychologists and nutritionists, in order to ensure holistic care for victims of violence. This study collaborates with the discussions on the aforementioned themes. These are essential for a better understanding of the factors capable of interfering in the health of the elderly, in order to systematize the best way to assist them.

The scarcity of studies that investigated the relationship between violence and the nutritional status of the elderly person limited the theoretical deepening of this manuscript. Such fact expresses the need to amplify scientific production with the aforementioned objects of study, in order to support evidence-based practice.

\section{CONCLUSION}

It was verified a low prevalence of psychological and physical violence among community elderly. However, logistic regression found that those who were in a relationship and malnourished were more likely to experience psychological violence. In addition, physical violence predominated among the elderly who do not have a labor activity.

\section{REFERENCES}

1. Ferretti C. Alterações fisiológicas doenças e manifestações clínicas em geriatria. 10 ed. São Paulo: Editora Senac; 2019.

2. Hall JE, Karch DL, Crosby AE, compilers. Elder abuse surveillance: uniform definitions and recommended core data elements. Version 1.0. Atlanta (GA): National Center for Injury Prevention and Control, Centers for Disease Control and Prevention, 2016 [cited 2020 Apr 9]. Available from: https://www.cdc.gov/violenceprevention/ pdf/EA_Book_Revised_2016.pdf

3. Ho CS, Wong SY, Chiu MM, Ho RC. Global prevalence of elder abuse: a metaanalysis and meta-regression. East Asian Arch Psychiatry. 2017 [cited 2020 Apr 9];27(2):43-55. Available from: https://www.easap.asia/index.php/component/ k2/item/771-1703-v27n2-p43

4. Castro VC, Rissardo LK, Carreira L. Violence Against the Brazilian elderlies: na analysis of hospitalizations. Rev Bras Enferm. 2018;71(2):830-8. doi: https:// doi.org/10.1590/0034-7167-2017-0139

5. Curcio CL, Payán-Villamizar C, Jiménez A, Gómez F. Abuse in Colombian elderly and its association with socioeconomic conditions and functionality. Colombia Med. 2019:50(2):77-88. doi: http://doi.org/10.25100/cm.v50i2.4013

6. Veras RP. Questionário Boas: questionário multidimensional para estudos comunitários na população idosa do Rio de Janeiro. Rio de Janeiro;19--. 
7. Hasselmann MH, Reichenheim ME. Adaptação transcultural para o português do instrumento Conflict Tactics Scales Form R (CTS-1), usada para aferir violência no casal: equivalências semânticas e de mensuração. Cad Saude Publica. 2003 [cited 2020 Apr 9];19(4):1083-93. Available from: https://doi.org/10.1590/ S0102-311X2003000400030

8. Nestlé Health Science \& Nestlé Nutrition Institute: Q\&A [interview] [Internet]. Today's Wound Clinic 2016 [cited 2020 Apr 9];10(11). Available from: https://www.todayswoundclinic.com/articles/ nestle-health-science-nestle-nutrition-institute-qa

9. Knight L, Hester M. Domestic violence and mental health in older adults. Int Rev Psychiatry. 2016;28(5):464-74. doi: https://doi.org/10.1080/09540261. 2016.1215294

10. Ferreira MF, Moraes CL, Reichenheim ML, Verly Junior E, Marques ES, SalesCosta, R. Effect of intimate partner violence on body mass index in low-income adult women. Cad Saude Publica. 2015;31(1):161-72. doi: https://doi. org/10.1590/0102-311X00192113

11. Defante LR, Nascimento LDO, Lima-Filho DO. Comportamento de consumo de alimentos de famílias de baixa renda de pequenas cidades brasileiras: 0 caso de Mato Grosso do Sul. Interações (Campo Grande). 2015;16(2):265-76. doi: https:// doi.org/10.1590/151870122015203

12. Santos AMR, Silva FL, Rodrigues RAP, Sá GGM, Santos JDM, Andrade EMLR, et al. Financial-patrimonial Elder abuse: na integrative review. Rev Bras Enferm. 2019;72(suppl. 2):343-51. doi: https://doi.org/10.1590/0034-7167-2018-0703
13. Mcdougal L, Klugman J, Dehingia N, Trivedi A, Raj A. Financial inclusion and intimate partner violence: what does the evidence suggest? PLOS One. 2019;14(10):e0223721. doi: https://doi.org/10.1371/journal.pone.0223721

14. Santos AMR, Nolêto RDS, Rodrigues RAP, Andrade EMLR, Bonfim EG, Rodrigues, TS. Economic-financial and patrimonial elder abuse: a documentary study. Rev Esc Enferm USP. 2019;53:e03417. doi: https://doi.org/10.1590/ s1980-220x2017043803417

15. Gomes AR. Machocracia, negacionismo histórico e violência no Brasil contemporâneo. Ñanduty. 2019 [cited 2020 Apr 9];7(10):146-58. Available from: http://ojs.ufgd.edu.br/index.php/nanduty/article/view/10303/5279

16. Indu PV. Mental health implications of elder abuse and domestic violence. Indian J Psychol Med. 2018;40(6):507-8. doi: https://doi.org/10.4103/IJPSYM. IJPSYM_438_18

17. Gesch, CB. The potential of nutrition to promote physical and behavioural wellbeing. In: Huppert FA, Baylis N, Keverne B, editors. The science of well-being. Oxford: Oxford University Press; 2005. Chapter 7. doi: https://doi.org/10.1093/ acprof:0so/9780198567523.003.0007

18. Parker GB, Brotchie H, Graham RK. Vitamin D and depression. J Affect Disord. 2017;208:56-61. doi: https://doi.org/10.1016/j.jad.2016.08.082

19. Aruma EO, Hanachor ML. Abraham Maslow's hierarchy of needs and assessment of needs in community development. Int J Dev Econ Sustain. 2017 [cited 2020 Apr 9];5(7):15-27. Available from: http://www.eajournals.org/wp-content/uploads/ Abraham-Maslow\%E2\%80\%99s-Hierarchy-of-Needs-and-Assessment-ofNeeds-in-Community-Development.pdf

20. Braga GC, Silva JV. Teorias de Enfermagem. 1 ed. São Paulo: Iatria; 2011. 


\section{- Authorship contribution:}

Wesley Ferreira de Moraes Brandão: Methodology,

Visualization, Writing-review \& editing.

Matheus Araruna de Souza: Methodology, Visualization,

Writing-original draft, Writing-review \& editing.

Gleicy Karine Nascimento de Araújo: Data curation,

Investigation, Software.

Renata Clemente dos Santos: Formal analysis,

Methodology, Software, Supervision, Validation,

Writing-review \& editing.

Luana Rodrigues de Almeida: Validation, Writing-review \& editing.

Rafaella Queiroga Souto: Conceptualization, Project administration, Resources, Supervision, Validation.

The authors declare that there is no conflict of interest.

- Corresponding author:

Rafaella Queiroga Souto

E-mail: rqs@academico.ufpb.br

Associate editor:

Graziella Badin Alit 